\title{
ANALISIS PENGARUH ADOPSI ISPO TERHADAP PERBAIKAN KINERJA PENGELOLAAN LINGKUNGAN DAN PERUBAHAN SOSIAL EKONOMI MASYARAKAT
}

\section{Analysis of ISPO Adoption Effect to Environmental Management Improvement and Social Economic Change of the Community}

\author{
M. Imam Arifandy ${ }^{\mathrm{a}}$, Hariyadi ${ }^{\mathrm{b}}$, Soeryo Adiwibowo ${ }^{\mathrm{c}}$ \\ ${ }^{a}$ Departemen Pengelolaan Sumberdaya Alam dan Lingkungan, Fakultas Multidisiplin, Institut Pertanian Bogor, \\ Kampus IPB Baranangsiang, Bogor 16680 -arifandyimam@gmail.com \\ ${ }^{b}$ Departemen Agronomi dan Holtikultura, Fakultas Pertanian, Institut Pertanian Bogor, Kampus IPB Darmaga, \\ Bogor 16680 \\ ${ }^{c}$ Departemen Sains Komunikasi dan Pengembangan Masyarakat, Fakultas Ekologi Manusia, Institut Pertanian \\ Bogor, Kampus IPB Darmaga, Bogor 16680
}

\begin{abstract}
Indonesian Sustainability Palm Oil (ISPO) is requirement for palm oil private business in the effort to preserve the environment, increase economic activities, and social activities of the community. The environmental management conducted by the company is analyzed by qualitative descriptive approach by comparing the condition of management before and after the implementation of ISPO. Measurement of the influence of CSR program as implementation in ISPO to the changing socio-economic condition of the community is done by quantitative approach with simple linear regression statistic analysis method. This study aims, first to analyze eh impacts of ISPO adoption in improving the environmental management performances of the company, second to analyze the influence of CSR program to the socio-economic condition of the community. ISPO implementation impacts on; first, environmental benefits obtained by the company include; (1) increase discharge and quality of processed wastewater for Land Application, (2) reduce of $\mathrm{CO}_{2}$ emissions 2.134.299 tons/year; (3) reduce of air emission and noise level in plant area; (4) reduce case of land fires and work accidents, (5) improve groundwater quality and Kandis river water quality, (6) improve of worker's capability and welfare. Second, the economic benefits obtained by the company, including; (1) increase of CPO production by 827 tons/year, and PKO production by 75 tons/year, (2) cost savings IDR 98.228.703/year from IPAL management improvements, and (3) Increase of company's revenue from selling hazardous waste to third party by IDR 343.734.000/year. Third, CSR program positively increase of community's income, education improvement of community family member, and better public perception to company.
\end{abstract}

Keywords: Environmental management, CSR, ISPO, social economic.

(Diterima: 31-07-2017; Disetujui: 30-10-2017)

\section{Pendahuluan}

\subsection{Latar Belakang}

Kelapa sawit adalah salah satu sumber daya alam yang menjadi komoditas utama pertanian di Indonesia yang memiliki keunggulan produktivitas dalam menghasilkan Crude Palm Oil (CPO) yang diolah dari hasil pemanenan kelapa sawit dalam bentuk Tandan Buah Segar (TBS). Tahun 2014, Indonesia memiliki luas perkebunan kelapa sawit yang mencapai $11,444,808$ ha yang tersebar berdasarkan berbagai status pengusahaan, seperti Perkebunan Rakyat, Perkebunan Besar Negara, dan Perkebunan Besar Swasta, dengan total produksi perkebunan kelapa sawit di Indonesia pada tahun 2015 mencapai 30.948.931 juta ton/tahun Crude Palm Oil (CPO) atau minyak sawit mentah (Ditjenbun, 2015).

Industri kelapa sawit di Indonesia pada tahun 2014 memiliki volume ekspor minyak sawit yang mencapai angka 12,399,598 juta ton dengan nilai 10,089,572 US\$. Provinsi dengan areal perkebunan kelapa sawit terbesar di Indonesia adalah Provinsi Riau yang mencapai luas 2,398,328 ha dengan total produksi kelapa sawit mencapai 7,442,557 ton/tahun. Besarnya produksi dan nilai ekspor kelapa sawit di Indonesia tidak terlepas dari adanya kendala dan tantangan yang harus dihadapi, salah satunya adalah kendala tuntutan pasar global terhadap produk kelapa sawit yang bersumber dari pengelolaan kelapa sawit yang ramah lingkungan (Ditjenbun, 2015).

Salah satu upaya pemerintah adalah dirumuskannya kebijakan melalui Kementrian Pertanian yang mewajibkan bagi seluruh pelaku usaha kelapa sawit yang terintegrasi dengan pengolahan untuk menerapkan Indonesian Sustainability Palm Oil (Rachmawati, 2015). Ketentuan ini diatur dalam Peraturan Menteri Pertanian Nomor: 19/Permentan/OT.140/3/2011, tentang Pedoman Perkebunan Kelapa Sawit Berkelanjutan Indonesia yang ditetapkan tanggal 29 Maret 2011 (Kementan, 2015).

ISPO terdiri dari 7 prinsip dan kriteria yang harus dipenuhi oleh perusahaan, salah satunya prinsip dan 
kriteria adalah tanggungjawab sosial dan pemberdayan masyarakat. Bentuk tanggung jawab sosial yaitu berupa program peningkatan pendapatan masyarakat dan mempertahankan kearifan lokal. Tanggung jawab sosial menunjukan komitmen terhadap pembangunan yang bekelanjutan dan pengelolaan kinerja sosial, ekonomi dan lingkungan (Hasibuan, 2006). Implementasi tanggungjawab sosial dalam ISPO oleh Perusahaan yang melakukan kegiatan usaha perkebunan kelapa sawit perlu untuk mempertimbangkan sikap dan persepsi masayarakat, karena hal juga akan mempengaruhi perkembangan perusahaan serta interaksi antara perusahaan dan masyarakat (Ahyari, 2002).

Penelitian Syahza (2007) menjelaskan bahwa pembangunan perkebunan kelapa sawit dapat mengurangi ketimpangan pendapatan antar golongan masyarakat dan meningkatkan kesejahteraan masyarakat sekitar serta meningkatkan pendidikan anggota masyarakat. Hal tersebut dapat terjadi karena dalam kriteria ISPO, terkandung kewajiban bagi perusahaan untuk memiliki komitmen sosial, yang diwujudkan melalui program-program Corporate Social Responsibility (CSR) dalam upaya melakukan tanggung jawab sosial dan pemberdayan ekonomi masyarakat.

\subsection{Rumusan Masalah}

Berdasarkan hasil penelitian Rachmawati (2105), adopsi ISPO dalam kegiatan usaha perkebunan dapat memperbaiki kinerja perusahaan dalam melakukan pengelolaan lingkungan hidup, melalui penerapan indikator-indikator pada prinsip dan kriteria ISPO. Septiawan (2015) dalam penelitiannya mengemukakan bahwa penerapan ISPO PKS Batu Ampar PT SMART Tbk telah mencapai kinerja pengelolaan lingkungan meliputi: pemanfaatan sumber energi terbaharukan yang menghasilkan energi sebesar 5,0664 juta KWh, penghematan solar sebesar 1,677,615.89 liter, penurunan emisi sebesar 70.63 ton $\mathrm{CO}_{2} /$ tahun, penghematan pupuk kimia senilai Rp. 5,750,080/ha/tahun. Namun, perlu diteliti lebih lanjut mengenai perbaikan kinerja pengelolaan lingkungan hidup dapat menjamin adanya peningkatan profit perusahaan yang mengadopsi ISPO tersebut. Perbaikan-perbaikan kinerja pengelolaan lingkungan hidup dapat dikaji dalam berbagai indikator yang terdapat dalam kriteria ISPO. Oleh karena itu, dalam konteks PT. Perkebunan Nusantara V, perlu dikaji lebih lanjut mengenai Seberapa besar perbaikan kinerja pengelolaan lingkungan hidup akibat adopsi ISPO dapat meningkatkan manfaat bagi PT. Perkebunan Nusantara V?

Salah satu tujuan dalam implementasi ISPO adalah diharapkan mampu untuk membangun industri kelapa sawit yang diselenggarakan berdasarkan asas kedaulatan, kemandirian, kebermanfaatan, keberlanjutan, keterpaduan, kebersamaan, keterbukaan, efisiensi-berkeadilan, kearifan lokal, kelestarian fungsi lingkungan (Permentan, 2015). Penelitian Syahza (2007) menjelaskan bahwa pembangunan perkebunan kelapa sawit dapat mengurangi ketimpangan pendapatan antar golongan masyarakat dan mengurangi ketimpangan ekonomi antar kabupaten/kota, menciptakan multiplier effect ekonomi dan meningkatkan kesejahteraan masyarakat sekitar. Hal tersebut dapat terjadi karena dalam kriteria ISPO, terkandung kewajiban bagi perusahaan untuk memiliki komitmen sosial, yang diwujudkan melalui program-program Corporate Social Responsibility (CSR) dalam upaya melakukan tanggung jawab sosial dan pemberdayan ekonomi masyarakat (Permentan, 2015). Maka, menjadi pertanyaan untuk diteliti lebih lanjut adalah Sejauh mana program CSR PT. Perkebunan Nusantara V membawa perubahan pada kondisi sosial-ekonomi masyarakat sekitar kawasan perkebunan terkait implementasi ISPO?

\subsection{Tujuan Penelitian}

Berdasarkan latar belakang tersebut, maka tujuan penelitian ini adalah:

1. Menganalisis pengaruh adopsi ISPO terhadap perbaikan kinerja pengelolaan lingkungan PT. Perkebunan Nusantara V yang kemudian berdampak lanjut terhadap manfaat yang dapat diperoleh oleh PT Perkebunan Nusantara V.

2. Menganalisis pengaruh program CSR sebagai salah satu elemen dalam ISPO PT. Perkebunan Nusantara $\mathrm{V}$ terhadap perubahan kondisi sosial ekonomi masyarakat.

\section{Metode Penelitian}

Penelitian ini dilakukan di Pabrik Kelapa Sawit (PKS) Sungai Galuh PT. Perkebunan Nusantara V di Kabupaten Kampar, Provinsi Riau. Penelitian ini dilakukan pada bulan Maret 2016 sampai dengan Mei 2016.

Populasi dalam penelitian ini berjumlah sebanyak 3,983 orang individu yang menjadi mitra binaan PTPN V. Responden yang dijadikan sampel penelitian adalah individu yang terlibat aktif menjadi mitra binaan dalam program CSR PTPN V. Responden yang dijadikan sampel pada penelitian ini berjumlah 40 orang individu dilakukan dengan teknik pengambilan Simple Random Sampling.

Analisis kinerja pengelolaan lingkungan perkebunan berdasarkan ISPO dilakukan dengan pendekatan kualitatif yang kemudian dipaparkan secara deskriptif. Analisis dilakukan dengan cara mengumpulkan berbagai informasi terkait dengan pengelolaan lingkungan perkebunan kelapa sawit saat sebelum adopsi ISPO (2014) dan sesudah adopsi ISPO (2016) yang didasarkan pada prinsip dan kriteria ISPO pada Permentan No. 11 Tahun 2015.

Analisis pengaruh program CSR terhadap kondisi sosial ekonomi masyarakat diperoleh dari data kuisioner yang kemudian dianalisis secara kuantitatif. Data kuisioner yang diperoleh dari responden selanjutnya dilakukan analisis statistik korelasi regresi 
linier. Pengolahan data menggunakan bantuan piranti lunak IBM SPSS 24.0 dan Microsoft Excel 2016.

\section{Hasil dan Pembahasan}

\subsection{Perbaikan Kinerja berdasarkan Prinsip dan Kriteria Manajemen Perkebunan}

Adopsi ISPO mulai dilakukan oleh PKS sungai Galuh pada 17 Juni 2015. Setelah adanya adopsi tersebut manajemen PKS Sungai Galuh mulai memperbaiki kinerja manajemen perkebunan dengan memperbaharui Standar Operational Procedure (SOP) sortasi masuk TBS pihak ketiga, dan TBS plasma, serta perbaharuan SOP panen dari brondol 2 manjadi brondol 5.

Tabel 1 menunjukkan adanya peningkatan hasil olah TBS sesudah adopsi ISPO dibandingkan dengan sebelum adopsi ISPO. Peningkatan produksi tersebut terjadi karena rendemen yang lebih tinggi di bandingkan dengan produksi 2014, peningkatan rendemen terjadi karena perbaikan pe nerimaan tingkat kematangan dan tingkat pemanenan buah dari TBS sortasi

Tabel 1. Pengolahan hasil PKS Sungai Galuh

\begin{tabular}{|c|c|c|c|c|c|c|}
\hline Jenis & Produksi & Satuan & $\begin{array}{c}\text { Sebelum ISPO } \\
\text { (2014) }\end{array}$ & $\begin{array}{c}\text { Sesudah ISPO } \\
(2016)\end{array}$ & Mutu & Acuan \\
\hline \multirow[t]{7}{*}{$\mathrm{CPO}$} & Hasil & Ton & 40,898 & 41,725 & & \\
\hline & Rendemen & $\%$ & 18.78 & 25.68 & Min 22.01 & \\
\hline & ALB & $\%$ & 6.29 & 3.71 & Maks 5.00 & SNI 01-2901-2006 \\
\hline & Kadar Air & $\%$ & 0.30 & 0.20 & Maks 0.25 & SNI 01-2901-2006 \\
\hline & Kadar Kotoran & $\%$ & 0.22 & 0.01 & Maks 0.25 & SNI 01-2901-2006 \\
\hline & DOBI & $\%$ & 2.70 & 5.02 & Min. 2.80 & Codex, Stan 210-1999 \\
\hline & $\beta$-Karoten & ppm & 446 & 1,528 & Min.500 & Codex, Stan 210-1999 \\
\hline \multirow[t]{5}{*}{$\mathrm{PKO}$} & Hasil & Ton & 10,973 & 11,048 & & \\
\hline & Rendemen & $\%$ & 5.04 & 6.80 & Min. 5.00 & Dept. Industri 2007 \\
\hline & ALB & $\%$ & 1.89 & 0.88 & Maks. 2.00 & SNI 01-0008-1987 \\
\hline & Kadar air & $\%$ & 0.72 & 0.34 & Maks. 0.45 & SNI 01-0008-1987 \\
\hline & Kadar Kotoran & $\%$ & 0.16 & 0.03 & Maks. 0.05 & SNI 01-0008-1987 \\
\hline (hasil & $\begin{array}{l}\text { TBS olah } \\
\text { O + hasil CPO) }\end{array}$ & Ton & 217,454 & 162,481 & & \\
\hline
\end{tabular}

Hasibuan (2012) dalam penelitiannya menjelaskan bahwa Kelapa sawit bermutu prima Special Quality (SQ) memiliki rendemen $22.1 \%-22.2 \%$. Selain itu, pengukuran mutu hasil CPO Indonesia juga didasarkan pada Standar Nasional Indonesia (SNI) No. 01-29012006 mengenai standarisasi mutu CPO nasional, dan juga standar internasional berdasarkan CODEX STAN 210-1999 untuk parameter karoten dan Deterioration of Bleachability Index (DOBI).

Perbaikan kinerja yang dilakukan oleh perusahaan mampu memperbaiki kualitas CPO dan PKO yang memenuhi Standar Nasional Indonesia dan juga Standar Internasional. Selain itu juga meningkatkan produksi hasil CPO dan PKO dengan rendemen yang tinggi.

\subsection{Perbaikan Kinerja berdasarkan Prinsip dan} Kriteria Pengelolaan dan Pemantauan Lingkungan

\section{a. Instalasi Pengolahan Limbah Cair / IPAL}

Sebelum adopsi ISPO, limbah sisa olah TBS pada IPAL PKS Sungai Galuh mencapai volume rata-rata sebesar $782 \mathrm{~m}^{3} /$ hari sebagai Land Application pada areal kebun seluas $60 \mathrm{Ha}$ dan sisanya dialirkan ke sungai Kandis. Sesudah adopsi ISPO, manajemen PKS
Sungai Galuh menerapkan perbaikan kinerja pemeliharaan IPAL untuk meningkatkan konsentrasi kualitas air limbah sehingga Land Applicaion dapat diterapkan dengan lebih baik. Pada tahun 2016, volume limbah cair untuk Land Application mencapai 1.080 $\mathrm{m}^{3} /$ hari. Meningkat sebesar $39 \%$ dari tahun 2014 . Perbaikan kinerja IPAL ditempuh melalui; (1) Pembersihan area IPAL setiap bulan, (2) Pengecekan kualitas air limbah bulanan, (3) Pengorekan scum pada kolam IPAL setiap 4 bulan, dan (4) Meningkatkan tinggi bantalan kolam sekali setahun, dan (5) Pengawasan harian terhadap sirkulasi pompa.

Berdasarkan Permen LH No. 01 tahun 2010 Tentang Tata Laksana Pengendalian Pencemaran Air, kategori karakteristik konsentrasi pencemar sebelum adopsi ISPO (2014) tergolong kepada konsentrasi pencemar sedang. Sedangkan sesudah adopsi ISPO (2016), kategori karakteristik pencemar berada pada kategori pencemar rendah. Hal ini menunjukkan adanya penurunan kadar pencemar pada saat sebelum adopsi ISPO dan sesudah adopsi ISPO.

Pengukuran parameter didasarkan pada Permen LH No. 05 Tahun 2014 Tentang Baku Mutu Air Limbah. Tabel 3 menunjukkan bahwa sesudah ISPO diadopsi (tahun 2016), seluruh parameter kualitas air limbah 
yang telah diolah telah memenuhi standar baku mutu nasional untuk air limbah, sehingga air limbah dapat dimanfatkan lebih untuk Land Application yang lebih luas sekaligus meminimalisir potensi pencemaran tanah dan air bawah tanah.

Adanya perbaikan kinerja perusahaan setelah adopsi ISPO ke dalam manajemen telah memberikan manfaat bagi PKS Sungai Galuh dalam melakukan pengolahan air limbah melalui IPAL, diantaranya; (1) peningkatan debit limbah yang dialirkan ke areal Land Application sebesar $1.080 \mathrm{~m}^{3} /$ hari, (2) perbaikan kualitas air limbah yang dialirkan pada areal Land Application, dan (3) penghematan biaya operasional pengolahan air limbah sebesar Rp. 98,228,703.

\section{b. Pengelolaan Limbah B3}

Sebelum adopsi ISPO (tahun 2014), PKS Sungai Galuh menghasilkan limbah B3 terbanyak yaitu pada jenis limbah air sisa olahan TBS sebanyak rata-rata 82,987 Ton/bulan. Limbah tersebut kemudian dapat diolah untuk dimanfaatkan kembali sebesar 63,604 ton/bulan.

Pada tahun 2016, sesudah adanya adopsi ISPO, langkah yang diambil oleh manajemen PKS Sungai Galuh untuk mengelola limbah B3 yang dihasilkan dengan memanfaatkan kembali 99.2\% limbah sisa olah TBS untuk areal tanaman juga menambah kerja sama menjadi 3 pihak untuk penampung limbah lainnya. Sesudah adopsi ISPO, limbah B3 yang tersisa adalah jenis air limbah sisa olah TBS, sedangkan limbah lainnya sudah diberikan kepada pihak ketiga.
Selain pemanfaatan limbah cair sisa olah TBS, sesudah adanya adopsi ISPO, PKS Sungai Galuh juga melakukan pemanfaatan 23,570,371 kg limbah sisa cangkang, dan serabut (fibre) dengan pembagian proporsi $50 \%$ (11.785.185 Kg/tahun) untuk bahan bakar Boiler dan tungku bakar, dan 50\% (11.785.185 $\mathrm{Kg} /$ tahun) digunakan untuk dijadikan Land Application sebagai mulching/serasah pada area kebun. Sebelum adopsi ISPO, manajemen mengalokasikan 100\% limbah sisa cangkang, tankos, dan serabut untuk bahan bakar boiler. Pemanfaatan limbah sisa cangkang dan fibre oleh manajemen PKS Sungai Galuh bertujuan untuk mengurangi emisi $\mathrm{CO}_{2}$ sesuai dengan kewajiban yang tertera dalam ISPO.

Sihombing dan Ardilla (2012) dalam penelitiannya menjelaskan Boiler dalam pemrosesan Fresh Fruit Bench (FFB) dapat memanfaatkan bahan bakar limbah FFB yaitu cangkang dan fiber kelapa sawit sehingga neraca emisi dapat ditekan karena emisi yang dilepaskan pada pembakaran cangkang dan serat di boiler merupakan hasil serapan karbon selama masa budidaya. Pemanfaatan cangkang dan serat sebagai bahan bakar pada boiler diharapkan mampu mensubstitusi penggunaan bahan bakar fosil seperti batubara dan BBM, sehingga emisi $\mathrm{CO}_{2}$ dapat diminimalkan.

Hasil pemanfaatan limbah cangkang dan serabut secara 50:50 tersebut mampu mengurangi emisi $\mathrm{CO}_{2}$ rata-rata sebesar 2,134,299 ton/tahun (Tabel 6). Selain itu, dengan adanya penjualan limbah cangkang dan serabut kepada pihak ketiga, mampu memberikan pendapatan lebih kepada perusahaan rata-rata sebesar Rp. 343,734,000/tahun.

Tabel 2. Emisi gas buang pada boiler dan genset

\begin{tabular}{|c|c|c|c|c|c|c|c|c|}
\hline \multirow[b]{2}{*}{ Tahun } & \multirow[b]{2}{*}{ Parameter } & \multirow[b]{2}{*}{ Satuan } & \multicolumn{3}{|c|}{ Boiler } & \multicolumn{3}{|c|}{ Genset } \\
\hline & & & Boiler 1 & Boiler 2 & $\begin{array}{l}\text { NAB } \\
\text { boiler }\end{array}$ & Genset 1 & Genset 2 & $\begin{array}{l}\text { NAB } \\
\text { genset }\end{array}$ \\
\hline \multirow[t]{10}{*}{2014} & Emisi Partikel & $\mathrm{Mg} / \mathrm{m}^{3}$ & 377.80 & 367.37 & 300.00 & 187.57 & 139.46 & 150.00 \\
\hline & $\mathrm{SO}_{2}$ & $\mathrm{Mg} / \mathrm{m}^{3}$ & 190.58 & 105.81 & 600.00 & 70.81 & 31.44 & 800.00 \\
\hline & $\mathrm{NO}_{2}$ & $\mathrm{Mg} / \mathrm{m}^{3}$ & 94.53 & 45.76 & 800.00 & 91.06 & 36.44 & 400.00 \\
\hline & $\mathrm{CO}$ & $\mathrm{Mg} / \mathrm{m}^{3}$ & - & - & - & 671.76 & 37.40 & 600.00 \\
\hline & Kec. Alir & $\mathrm{m} /$ detik & 22.30 & 23.10 & 20.00 & 22.67 & 21.60 & 20.00 \\
\hline & Opasitas & $\%$ & 20.00 & 20.00 & 30.00 & 27.50 & 17.50 & 20.00 \\
\hline & $\mathrm{HCl}$ & $\mathrm{Mg} / \mathrm{m}^{3}$ & 3.31 & 2.08 & 5.00 & - & - & - \\
\hline & Klorin/ $\mathrm{Cl}_{2}$ & $\mathrm{Mg} / \mathrm{m}^{3}$ & 0.90 & 0.58 & 5.00 & - & - & - \\
\hline & Ammonia/ $\mathrm{NH}_{3}$ & $\mathrm{Mg} / \mathrm{m}^{3}$ & 0.58 & 0.17 & 1.00 & - & - & - \\
\hline & $\mathrm{HF}$ & $\mathrm{Mg} / \mathrm{m}^{3}$ & 0.53 & 0.21 & 8.00 & - & - & - \\
\hline \multirow[t]{10}{*}{2016} & Emisi partikel & $\mathrm{Mg} / \mathrm{m}^{3}$ & 164.23 & 161.62 & 300.00 & 49.46 & 100.26 & 150.00 \\
\hline & $\mathrm{SO}_{2}$ & $\mathrm{Mg} / \mathrm{m}^{3}$ & 61.06 & 31.23 & 600.00 & 25.15 & 22.25 & 800.00 \\
\hline & $\mathrm{NO}_{2}$ & $\mathrm{Mg} / \mathrm{m}^{3}$ & 42.40 & 58.74 & 800.00 & 84.01 & 34.83 & 400.00 \\
\hline & $\mathrm{CO}$ & $\mathrm{Mg} / \mathrm{m}^{3}$ & - & - & - & 223.00 & 18.40 & 600.00 \\
\hline & Kec. Alir & $\mathrm{m} /$ detik & 3.56 & 4.79 & 20.00 & 19.00 & 17.45 & 20.00 \\
\hline & Opasitas & $\%$ & 15.00 & 15.00 & 30.00 & 18.00 & 18.00 & 20.00 \\
\hline & $\mathrm{HCl}$ & $\mathrm{Mg} / \mathrm{m}^{3}$ & 1.88 & 0.72 & 5.00 & - & - & - \\
\hline & Klorin/ $\mathrm{Cl}_{2}$ & $\mathrm{Mg} / \mathrm{m}^{3}$ & 0.05 & 0.02 & 5.00 & - & - & - \\
\hline & Ammonia/ $\mathrm{NH}_{3}$ & $\mathrm{Mg} / \mathrm{m}^{3}$ & 0.10 & 0.04 & 1.00 & - & - & - \\
\hline & $\mathrm{HF}$ & $\mathrm{Mg} / \mathrm{m}^{3}$ & 0.15 & 0.05 & 8.00 & - & - & - \\
\hline
\end{tabular}

c. Penanganan Gangguan Sumber Tidak Bergerak Gangguan sumber tidak bergerak yang ada di lokasi PKS Sungai Galuh terdiri dari emisi dan tingkat kebisingan oleh aktivitas genset, dan boiler. Parameter emisi boiler mengacu pada Permen LH No. 07 Tahun 2007, parameter emisi genset mengacu pada Permen LH No. 21 Tahun 2008, dan parameter kebisingan mengacu pada Kepmen LH No. 48 Tahun 1996. 
Perbaikan kinerja yang dilakukan manajemen PKS Sungai Galuh sesudah adopsi ISPO ialah; (1) Pembakaran $50 \%$ limbah cangkang untuk bahan bakar Boiler, (2) Perawatan dan pengecekan rutin mesin Boiler dan genset tiap bulan, (3) Pemasangan dust collector untuk menurunkan kadar polutan dari emisi, (4) Peningkatan jumlah tanaman hijau di sekitar area pabrik.

Pada Tabel 2, hasil pengukuran emisi pada boiler dan genset di PKS Sungai Galuh sebelum adopsi ISPO (2014) menunjukkan masih terdapat parameterparameter emisi yang berada di atas Nilai Ambang Batas (NAB). Sedangkan sesudah adopsi ISPO (2016), seluruh parameter emisi sudah berada di bawah Nilai Ambang Batas. Sebelum adopsi ISPO hasil pengukuran sebelum ISPO (2014) tingkat kebisingan pada area pemukiman adalah sebesar $51.3 \mathrm{~dB}$, tingkat kebisingan tersebut masih berada di atas baku mutu $(50.0 \mathrm{~dB})$, sedangkan setelah adopsi ISPO, tingkat kebisingan turun menjadi 46,8 dB dan sudah memenuhi baku mutu.

Perbaikan kinerja yang dilakukan manajemen PKS Sungai Galuh setelah adanya adopsi ISPO memberikan manfaat lingkungan yaitu; (1) penurunan parameterparameter emisi genset dan boiler yang memenuhi standar baku mutu berdasarkan pada Permen LH No. 07 Tahun 2007, dan Permen LH No. 21 Tahun 2008, serta (2) penurunan tingkat kebisingan area pemukiman menjadi di bawah angka baku mutu sesuai Kepmen LH No. 48 Tahun 1996.

\section{d. Pencegahan dan Penanggulangan Kebakaran}

Sebelum adopsi ISPO, manajemen PKS Sungai Galuh belum memiliki strategi preventif/pencegahan kebakaran, tindakan yang dilakukan oleh manajemen hanya sebatas tindakan represif/penanggulangan kebakaran berupa usaha pemadaman api pada lokasi kebakaran oleh Regu Pemadam Kebakaran (RPK) kebun. Sepanjang tahun 2014, terjadi 7 kasus kebakaran lahan pada area yang berbatasan dengan pemukiman penduduk.

Setelah adanya adopsi ISPO, PKS Sungai Galuh melakukan upaya preventif untuk mencegah kebarakan lahan yaitu; (1) patroli petugas di lokasi-lokasi rawan kebakaran setiap hari, terutama pada musim kemarau, (2) pemasangan rambu-rambu peringatan pada areal rawan yang berbatasan dengan lahan masyarakat, (3) pelengkapan sarana dan prasarana Alat Pemadam Api Ringan / APAR, (4) pembuatan sistem tanggap darurat kabakaran lahan, (5) pelaksanaan replanting tanpa mekanisme bakar, dan (6) sosialisasi kepada masyarakat serta pelatihan kepada karyawan terkait kebakaran lahan. Adanya perbaikan kinerja tersebut membuat kawasan PKS Sungai Galuh tidak pernah mengalami kasus kebakaran lahan.

\section{e. Konservasi Sumber dan Kualitas Air}

Sumber air yang terdapat kada kawasan perkebunan dan kawasan PKS Sungai Galuh adalah sungai Kandis. Pengukuran dan analisis untuk kualitas air dilakukan pada daerah hulu dan hilir sungai Kandis, serta juga melakukan pengukuran pada sumur penduduk, serta sumur pantau LA (Land Application) dan sumur pantau non-LA pada PKS Sungai Galuh.

Parameter pengukuran baku mutu kualitas air sungai Kandis diukur berdasarkan Peraturan Pemerintah No. 82 Tahun 2001 Tentang Pengelolaan Kualitas Air dan Pengendalian Pencemaran Air. Sedangkan pengukuran baku mutu kualitas air sumur pantau didasarkan pada Kepmen LH Nomor 28 Tahun 2003 Tentang Pedoman Teknis Pengkajian Pemanfaatan Air Limbah dari Industri Minyak Sawit pada Tanah di Perkebunan Kelapa Sawit.

Hasil pengukuran menunjukkan sebelum adopsi ISPO (2014) masih ditemukan parameter pencemar yang di atas angka baku mutu, pada sumur pantau maupun pada area hilir dan hulu sungai Kandis. Sesudah adopsi ISPO pada tahun 2016 hasil pengukuran menunjukkan adanya penurunan pencemaran sumber air jika dibandingkan sebelum adopsi. Hasil pengukuran pada sumur pantau Land Application / LA menunjukkan adanya penurunan kadar pencemaran dari keseluruhan parameter. Pada pengukuran areal Non-LA menunjukkan adanya penurunan pada parameter parameter $\mathrm{BOD}, \mathrm{NO}_{3}-\mathrm{N}$, $\mathrm{NH}_{3}-\mathrm{N}$, Timbal, Tembaga, Seng, dan Khlorida. Pada areal sumur penduduk, hasil pengukuran menunjukkan adanya penurunan parameter $\mathrm{DO}, \mathrm{NO}_{3}-\mathrm{N}, \mathrm{NH}_{3}-\mathrm{N}$, timbal, tembaga, seng, dan khlorida. Sesudah adopsi ISPO tersebut, keseluruhan parameter sumur pantau sudah memenuhi standar baku mutu berdasarkan Kepmen LH Nomor 28 Tahun 2003.

Tahun 2016 sesudah adopsi ISPO, seluruh parameter kualitas air hulu dan hilir sungai Kandis mengalami perbaikan mutu dibanding sebelum adopsi ISPO (tahun 2014) sehingga telah memenuhi standar baku mutu sesuai dengan Peraturan Pemerintah No. 82 Tahun 2001.

Upaya perbaikan kinerja yang dilakukan oleh pihak manajemen perkebunan dan PKS Sungai Galuh adalah; (1) memberhentikan aktivitas pembuangan limbah yang telah diolah ke aliran sungai Kandis ataupun sumber air lainnya, (2) Land Application terhadap limbah cair yang telah diolah ke areal perkebunan dengan persyaratan kedalaman air tanah $>2$ meter, Adanya perbaikan kinerja perusahaan setelah adopsi ISPO ke dalam manajemen telah memberikan manfaat bagi PKS Sungai Galuh dalam melakukan konservasi sumber dan kualitas air, diantaranya; (1) perbaikan kualitas air tanah, maupun kualitas sungai Kandis sebagai sumber air, (2) pemanfaatan 99,2\% dari total air limbah yang sudah diolah untuk Land Application areal perkebunan seluas $200 \mathrm{Ha}$.

\subsection{Perbaikan Kinerja berdasarkan Prinsip dan Kriteria Tanggungjawab terhadap Pekerja}

\section{a. Keselamatan dan Kesehatan Kerja (K3)}

Sebelum adopsi ISPO, penyediaan laporan kecelakaan kerja yang terdapat pada PKS Sungai Galuh hanya sebatas dokumen Berita Acara Kecelakaan Kerja, dan dokumen Laporan Penyidikan Kecelakaan dari Asisten. Pada tahun 2014, kasus kecelakaan kerja sebelum adanya adopsi ISPO, terdiri dari 4 kasus 
kecelakaan yang mengakibatkan cedera yang dialami oleh karyawan. Kecelakaan kerja tersebut terjadi akibat kerusakan fasilitas yang terdapat pada area pabrik pengolahan TBS.

Sesudah adopsi ISPO, penyediaan laporan kecelakaan kerja kemudian direvisi menjadi beberapa dokumen, diantaranya; dokumen Laporan Kecelakaan Kerja (Jamsostek), dokumen Laporan Temuan NonConformity Report / NCR \& Usulan Tindakan Perbaikan, dokumen Berita Acara Kronologis Kecelakaan Kerja, dan dokumen Laporan Awal Kecelakaan / Penyakit Akibat Kerja.

Adanya perbaikan kinerja K3 sesudah adopsi ISPO ke dalam manajemen telah memberikan manfaat bagi PKS Sungai Galuh dalam melakukan pencegahan kecelakaan kerja, terutama dengan adanya Laporan Temuan Non-Conformity Report / NCR \& Usulan Tindakan Perbaikan. Adanya mekanisme pelaporan tersebut mampu mencegah adanya kecelakaan kerja, karena setiap karyawan dapat melaporkan temuannya kepada manajemen, apabila ditemukan adanya potensipotensi yang menimbulkan kasus kecelakaan kerja. Adanya perbaikan kinerja dalam adopsi ISPO membuat manajemen PKS Sungai Galuh mampu mencapai target Zero Accident sesuai dengan yang tertera pada dokumen perencanaan jangka pendek perusahaan untuk tahun 2016.

\section{b. Peningkatan Kemampuan dan Kesejahteraan Pekerja}

Selama tahun 2016, Perusahaan telah mengeluarkan dana pelatihan dan pengembangan sebesar Rp. $5,365,410,670$ naik $10.56 \%$ terhadap tahun 2014 dan 2015 yang hanya mencapai Rp. 4,852,701,872. Dana pelatian tersebut ditujukan untuk 5 In-House Training dan 4 pelatihan yang diberikan kepada 558 orang karyawan.

Selain peningkatan kemampuan karyawan, sesudah adopsi ISPO, perusahaan juga mulai melakukan perbaikan kesejahteraan karyawan melalui sistem penggajian terendah sesuai Upah Minimum Regional (UMR) Kabupaten Kampar dan juga pemberian penghargaan bagi karyawan yang telah melakukan pengabdian di atas 20 tahun.

Berdasarkan Surat Keputusan Gubernur Riau Kpts. Nomor 1058/XI/2016 Tentang Upah Minimum Kabupaten/Kota se-Provinsi Riau, upah minimum Kabupaten Kampar adalah Rp. 2,315,002. Adanya SK Gubernur Riau tersebut serta kewajiban perusahaan dalam meningkatkan kesejahteraan sesuai yang tercantum dalam ISPO, maka manajemen PKS Sungai Galuh merevisi Perjanjian Kerja Bersama untuk karyawan dengan upah gaji karyawan golongan terendah adalah Rp. 2,377,000.

Perusahaan juga memfasilitasi terbentuknya Serikat Pekerja Perkebunan Nusantara (SP-BUN) PT Perkebunan Nusantara V pada tahun 2016. Sesuai dengan Perjanjian Kerja Bersama (PKB) yang berlaku di perusahaan, bahwa selain gaji, perusahaan juga memberikan jaminan sosial untuk pemenuhan kesejahteraan karyawan.

\subsection{Pengaruh Program CSR terhadap Perbaikan Kondisi Sosial dan Ekonomi Masyarakat}

Bentuk tanggung jawab sosial perusahaan terhadap masyarakat yang dilaksanakan oleh PTPN V yaitu dengan menerapkan Program CSR Kemitraan dan Bina Lingkungan (PKBL) dengan jumlah mitra binaan menjadi sebanyakan 3,983 orang, dan total penyaluran dana program Kemitraan sebesar Rp. 85,692,869,693.

Program CSR PKBL direalisasikan dalam bentuk penyaluran dana bergulir kepada masyarakat yang dibagi menjadi 3 kategori, yaitu kategori rendah, sedang, dan tinggi. Kategori rendah, adalah masyarakat yang menerima bantuan dana sebesar Rp. 10,000,000. kategori sedang adalah masyarakat yang menerima bantuan dana sebesar Rp. 15,000,000, sedangkan kategori tinggi adalah masyarakat yang menerima bantuan dana sebesar Rp. 20,000,000.

\section{a.Pengaruh Program CSR terhadap Peningkatan Pendapatan}

Berdasarkan data yang diperoleh dari kuisioner, diketahui bahwa sesudah menjadi mitra binaan program CSR Kemitraan, responden mengalami peningkatan pendapatan mulai dari Rp 500,000 hingga Rp. 2,500,000/bulan.

Hasil uji statistik regresi linier menunjukkan Nilai Korelasi (R) yaitu sebesar 0.479 nilai tersebut kemudian dikonsultasikan berdasarkan pedoman interpretasi nilai korelasi, maka dapat diinterpretasi bahwa hubungan antara penerimaan dana CSR dengan peningkatan pendapatan responden berada pada kategori korelasi sedang $(0.40<\mathrm{R}<0.59)$. Selain itu, hasil uji statistic juga menunjukkan nilai $R$ Square atau Koefisien Determinasi (KD) sebesar 0.229 sehingga dapat diinterpretasi bahwa variabel penerimaan dana CSR memiliki pengaruh sebesar $22.9 \%$ terhadap variabel persepsi responden dan lainnya $77.1 \%$ dipengaruhi oleh faktor-faktor lain di luar variabel penerimaan dana CSR.

Selain itu, perhitungan statistik juga menunjukkan nilai signifikansi (Sig.) sebesar 0.002 dan nilai F hitung sebesar 11.285. Berdasarkan hasil tersebut maka dapat diketahui bahwa nilai signifikansi $<0.05$ sehingga dapat diinterpretasi bahwa persamaan regresi antara penerimaaan dana CSR dan peningkatan pendapatan responden memiliki kriteria berkorelasi signifikan.

Hasil perhitungan koefisien regresi linier sederhana menunjukkan nilai $t_{\text {hitung }}$ sebesar 3.359. Selanjutnya dilakukan perhitungan $t_{\text {tabel }}$ pada software Microsoft Excel dengan rumus ( $=\operatorname{tinv}(\alpha / 2, \mathrm{df}))$ sehingga diperoleh nilai $t_{\text {tabel }}$ sebesar 2.333. Kemudian dapat diketahui $t_{\text {hitung }}(3.359)>t_{\text {tabel }}$ (2.333) sehingga dapat disimpulkan bahwa hipotesis $\mathrm{H}_{1}$ diterima yaitu Terdapat pengaruh besaran dana bantuan program CSR terhadap peningkatan pendapatan responden.

Berdasarkan kedua hasil uji hipotesis, yaitu hasil uji hipotesis dengan membandingkan nilai signifikansi dengan $\alpha$ (0.05) dan uji hipotesis dengan membandingkan $t_{\text {hitung }}$ dengan $t_{\text {tabel }}$, terbukti bahwa terdapat pengaruh signifikan antara besaran dana 
bantuan program CSR terhadap peningkatan pendapatan responden.

\section{b. Pengaruh Program CSR terhadap Peningkatan Pendidikan Anggota Keluarga}

Peningkatan pendidikan anggota keluarga dibagi menjadi 3 kategori. Peningkatan pendidikan rendah adalah anggota keluarga responden yang tidak mengalami peningkatan pendidikan, atau mengalami peningkatan pendidikan pada tingkatan yang sama/setara. Peningkatan pendidikan sedang adalah anggota keluarga responden yang mengalami peningkatan pendidikan pada tingkatan rendah ke sedang. Sedangkan peningkatan pendidikan tinggi, adalah anggota keluarga responden yang mengalami peningkatan pendidikan pada tingkatan sedang ke tinggi.

Tabel 3. Frekuensi peningkatan pendapatan

\begin{tabular}{crc}
\hline Peningkatan & \multicolumn{2}{c}{ Frekuensi } \\
\cline { 2 - 3 } pendidikan & $\sum$ & $\%$ \\
\hline Rendah & 11 & 27.5 \\
Sedang & 9 & 22.5 \\
Tinggi & 20 & 50.0 \\
\hline Total & 40 & 100.0 \\
\hline
\end{tabular}

Berdasarkan Tabel 3, diketahui bahwa sesudah mengikuti program CSR Kemitraan, mayoritas peningkatan pendidikan anggota keluarga responden berada pada tingkatan tinggi. Hal tersebut dapat dijelaskan karena sebaran frekuensi menunjukkan persentase dominan pada peningkatan pendidikan tinggi, sebesar $50.0 \%$.

Hasil uji statistik regresi linier menunjukkan menunjukkan Nilai Korelasi (R) yaitu sebesar 0.477 nilai tersebut kemudian dikonsultasikan berdasarkan pedoman interpretasi nilai korelasi, maka dapat diinterpretasi bahwa hubungan antara penerimaan dana CSR dengan peningkatan pendidikan anggota keluarga responden berada pada kategori korelasi sedang $(0.40<\mathrm{R}<0.59)$. Nilai $R$ Square atau Koefisien Determinasi (KD) sebesar 0.228 sehingga dapat diinterpretasi bahwa variabel penerimaan dana CSR memiliki pengaruh sebesar $22.8 \%$ terhadap variabel peningkatan pendidikan anggota keluarga responden dan lainnya $77.2 \%$ dipengaruhi oleh faktor-faktor lain di luar variabel penerimaan dana CSR.

Selain itu, perhitungan statistik juga menunjukkan nilai signifikansi (Sig.) sebesar 0.002 dan nilai F hitung sebesar 11.217. Berdasarkan hasil tersebut maka dapat diketahui bahwa nilai signifikansi $<0.05$ sehingga dapat diinterpretasi bahwa model persamaan regresi antara penerimaaan dana CSR dan peningkatan pendidikan anggota keluarga responden memiliki kriteria berkorelasi signifikan.

Hasil perhitungan koefisien regresi linier sederhana menunjukkan nilai $t_{\text {hitung }}$ sebesar 3.359. Selanjutnya dilakukan perhitungan $t_{\text {tabel }}$ pada software Microsoft Excel dengan rumus $(=\operatorname{tinv}(\alpha / 2, \mathrm{df}))$ sehingga diperoleh nilai $t_{\text {tabel }}$ sebesar 2.333. Kemudian dapat diketahui $t_{\text {hitung }}(3.349)>t_{\text {tabel }}(2.333)$ sehingga dapat disimpulkan bahwa hipotesis $\mathrm{H}_{1}$ diterima yaitu Terdapat pengaruh besaran dana bantuan program CSR terhadap peningkatan pendidikan anggota keluarga responden.

Berdasarkan kedua hasil uji hipotesis, yaitu hasil uji hipotesis dengan membandingkan nilai signifikansi dengan $\alpha$ (0.05) dan uji hipotesis dengan membandingkan $t_{\text {hitung }}$ dengan $t_{\text {tabel }}$, terbukti bahwa terdapat pengaruh signifikan antara besaran dana bantuan program CSR terhadap peningkatan pendapatan responden.

\section{c. Pengaruh Program CSR terhadap Peningkatan Persepsi Masyarakat}

Pengukuran persepsi masyarakat dengan menggunakan alat kuisioner skala Likert sebagai pengumpulan data yang berisi 20 pernyataan. Responden kemudian mengisi kuisioner tersebut sesuai dengan pembagian empat (4) kolom, yang terbagi menjadi sangat tidak setuju (STS) skor 1, tidak setuju (TS) skor 2, setuju (S) skor: 3, sangat setuju (SS) skor 4. Sehingga akan diperoleh nilai minimum 20, dan nilai maksimum 80.

Kategori persepsi masyarakat golongan rendah, jika jumlah skor Skala Likert 20-39, dan kategori persepsi masyarakat golongan sedang, jika jumlah skor Skala Likert 40-60, serta kategori persepsi masyarakat golongan tinggi, jika jumlah skor Skala Likert 61-80.

Tabel 4. Frekuensi persepsi masyarakat

\begin{tabular}{|c|c|c|c|}
\hline \multirow{2}{*}{ Persepsi } & \multirow{2}{*}{ interval } & \multicolumn{2}{|c|}{ Frekuensi } \\
\hline & & $\sum$ & $\%$ \\
\hline Rendah & $20-39$ & 3 & 7.5 \\
\hline Sedang & $40-60$ & 18 & 45.0 \\
\hline Tinggi & $61-80$ & 19 & 47.5 \\
\hline \multicolumn{2}{|c|}{ Total } & 40 & 100.0 \\
\hline
\end{tabular}

Hasil uji statistik regresi linier menunjukkan Nilai Korelasi (R) yaitu sebesar 0.762 nilai tersebut kemudian dikonsultasikan berdasarkan pedoman interpretasi nilai korelasi, maka dapat diinterpretasi bahwa hubungan antara penerimaan dana CSR dengan persepsi responden berada pada kategori korelasi kuat $(0.60<\mathrm{R}<0.79)$. Nilai menunjukkan $R$ Square atau Koefisien Determinasi (KD) sebesar 0.527 sehingga dapat diinterpretasi bahwa variabel penerimaan dana CSR memiliki pengaruh sebesar $52.7 \%$ terhadap variabel persepsi responden dan lainnya $47.3 \%$ dipengaruhi oleh faktor-faktor lain di luar variabel penerimaan dana CSR.

Selain itu, perhitungan statistik menunjukkan nilai signifikansi (Sig.) sebesar 0.000 dan nilai $F$ hitung sebesar 42.419. Berdasarkan hasil tersebut maka dapat diketahui bahwa nilai signifikansi $<0.05$ sehingga dapat diinterpretasi bahwa model persamaan regresi antara penerimaaan dana CSR dan persepsi responden memiliki kriteria berkorelasi signifikan.

Hasil perhitungan koefisien regresi linier sederhana menunjukkan nilai $t_{\text {hitung }}$ sebesar 6.513. Selanjutnya dilakukan perhitungan $\mathrm{t}_{\text {tabel }}$ pada software Microsoft Excel dengan rumus $(=\operatorname{tinv}(\alpha / 2, \mathrm{df}))$ sehingga diperoleh nilai $t_{\text {tabel }}$ sebesar 2.333. Kemudian dapat diketahui $\mathrm{t}_{\text {hitung }}(6.513)>\mathrm{t}_{\text {tabel }}(2.333)$ sehingga dapat disimpulkan 
bahwa $\mathrm{H}_{1}$ yaitu Terdapat pengaruh besaran dana bantuan program CSR terhadap persepsi responden.

Berdasarkan kedua hasil uji hipotesis, yaitu hasil uji hipotesis dengan membangingkan nilai signifikansi dengan $\alpha$ (0.05) dan uji hipotesis dengan membandingkan $t_{\text {hitung }}$ dengan $t_{\text {tabel }}$, terbukti bahwa terdapat pengaruh antara besaran dana bantuan program CSR terhadap persepsi responden.

\section{Kesimpulan}

Adanya adopsi ISPO telah memberikan manfaat terhadap perusahaan. Manfaat yang diterima oleh perusahaan melalui perbaikan kinerja pengelolaan lingkungan dalam implementasi ISPO dapat memperbaiki dan meningkatkan kondisi lingkungan perusahaan serta mampu meningkatkan pendapatan perusahaan dan menghemat biaya pengeluaran perusahaan.

Program CSR sebagai salah satu elemen dalam implementasi ISPO memiliki pengaruh signifikan terhadap peningkatan kondisi sosial ekonomi masyarakat. Berdasarkan uji statistik, adanya bantuan dana melalui program CSR Kemitraan dan Bina Lingkungan yang dilakukan oleh PT. Perkebunan Nusantara V berkorelasi positif terhadap peningkatan pendapatan masyarakat, peningkatan pendidikan anggota keluarga masyarakat, dan persepsi masyarakat terhadap perusahaan.

\section{Daftar Pustaka}

[1] [Ditjenbun] Direktorat Jendral Perkebunan, 2014. Statistik Perkebunan Indonesia. Jakarta, DITJENBUN.

[2] [KEMENLH] Kementrian Lingkungan Hidup Indonesia, 1996. Keputusan Mentri Lingkungan Hidup Indonesia Nomor 48 Tahun 1996 Tentang Baku Tingkat Kebisingan. Jakarta, KEMENLH.

[3] [KEMENLH] Kementrian Lingkungan Hidup Indonesia, 2003. Keputusan Mentri Lingkungan Hidup Indonesia Nomor 28 Tahun 2003 Tentang Pedoman Teknis Pengkajian Pemanfaatan Air Limbah dari Industri Minyak Sawit pada Tanah di Perkebunan Kelapa Sawit. Jakarta, KEMENLH.
[4] [KEMENLH] Kementrian Lingkungan Hidup Indonesia, 2007. Peraturan Mentri Lingkungan Hidup Indonesia Nomor 07 Tahun 2007 Tentang Baku Mutu Emisi Sumber Tidak Bergerak Bagi Ketel Uap. Jakarta, KEMENLH.

[5] [KEMENLH] Kementrian Lingkungan Hidup Indonesia, 2008. Peraturan Mentri Lingkungan Hidup Indonesia Nomor 21 Tahun 2008 Tentang Baku Mutu Emisi Sumber Tidak Bergerak Bagi Usaha dan/atau Kegiatan Pembangkit Tenaga Listrik Termal. Jakarta, KEMENLH.

[6] [KEMENLH] Kementrian Lingkungan Hidup Indonesia, 2010. Peraturan Mentri Lingkungan Hidup Indonesia Nomor 01 Tahun 2010 Tentang Tata Laksana Pengendalian Pencemaran Air. Jakarta, KEMENLH.

[7] [KEMENLH] Kementrian Lingkungan Hidup Indonesia, 2014. Peraturan Mentri Lingkungan Hidup Indonesia Nomor 05 Tahun 2014 Tentang Baku Mutu Air Limbah. Jakarta, KEMENLH.

[8] [KEMENTAN] Kementrian Pertanian Republik Indonesia, 2015. Peraturan Menteri Pertanian Republik Indonesia Nomor 11/Permentan/OT.140/3/2015 Tentang Sistem Sertifikasi Kelapa Sawit Berkelanjutan Indonesia (Indonesian Sustainable Palm Oil Certification System /ISPO). Jakarta, KEMENTAN.

[9] Ahyari, A., 2002. Manajemen Produksi dan Pengendalian Produksi. Yogyakarta, BFE.

[10] Hasibuan, H.A., 2012. Kajian Mutu dan Karakteristik Minyak Sawit Indonesia serta Produk Fraksinasinya. Jurnal Standardisasi. 14(1), pp. 13-21.

[11] Hasibuan, M., 2006. Manajemen Dasar, Pengertian, Dan Masalah. edisi revisi. Jakarta, Bumi aksara.

[12] Pemerintah Provinsi Riau, 2016. Surat Keputusan Gubernur Riau Kpts. Nomor 1058/XI/2016 Tentang Upah Minimum Kabupaten/Kota se Provinsi Riau. Pekanbaru, Sekretariat Daerah Riau.

[13] Pemerintah Republik Indonesia, 2001. Peraturan Pemerintah Republik Indonesia Nomor 82 Tahun 2001 Tentang Pengelolaan Kualitas Air dan Pengendalian Pencemaran Air. Jakarta, Sekretariat Negara.

[14] Rachmawati, N., 2105. Analisis Pengelolaan Lingkungan di Perkebunan Batu Ampar Estate PT. Tapian Nadenggan dalam Implementasi Indonesian Sustainability Palm Oil [tesis]. Bogor, Institut Pertanian Bogor.

[15] Sihombing, A.L., I. Ardilla, 2012. Perhitungan Emisi $\mathrm{CO}_{2}$ Bahan Bakar Biodiesel dari Kelapa Sawit. Jurnal M\&E. 10(2), Juni 2012. Jakarta, Puslitbang.

[16] Syahza, A., 2007. Percepatan Pemberdayaan Ekonomi Masyarakat Pedesaan dengan Model Agroestate Berbasis Kelapa Sawit. Jurnal Ekonomi XII/02/Juli/2007. Jakarta, Universitas Tarumanegara. 